\title{
POLITICAL EMIGRANTS, PRISONERS OF WAR AND INTERNED PERSONS FROM RUSSIA AND UKRAINE IN POMERELIA (GDAŃSK POMERANIA) IN 1914-1939
}

\author{
Zbigniew KARPUS (Nicolaus Copernicus University in Toruń) \\ ORCID: 0000-0001-5018-976X
}

\section{Introduction}

Recent Polish history witnessed practically a single case when the country became a shelter for a large number of escapees from other states. Usually it was Poles who, for political or economic reasons, emigrated to the countries of Western Europe or to Americas. In the early 1920 s refugees from the east, mostly Russians and Ukrainians, began to settle in the Pomeranian voivodeship. These groups included civilians escaping from Russia engulfed by the civil war as well as the members of military formations, in some instances with their families. They fought as Polish allies in the Polish-Soviet War in 1920. After the fighting in the east ended and the preliminary peace was signed on 12 October 1920, those formations lost the status of Polish allies. After a brief fight with much stronger Bolshevik forces, they crossed the Polish border again and subsequently were detained and placed in camps. Together with their families, at the moment of internment those formations amounted to approximately 50,000 persons. ${ }^{1}$ They were placed in hastily established camps; the last interned left the camps only in mid-1924. The living conditions in the camps were difficult, so part of the interned returned to their homes in the Soviet Russia - after amnesty was proclaimed at the end of 1921 — or left for Western Europe if they managed to find

\footnotetext{
${ }^{1}$ Zbigniew Karpus, Jeńcy i internowani rosyjscy i ukraińscy w Polsce w latach 1918-1924 (Toruń: Wydawnictwo Adam Marszałek, 1991), 112-114.
} 
work there. The others settled in Poland. The refugees from Russia, both in Poland and in other European countries, lost the citizenship of the Soviet Russia and received the status of stateless persons as well as Nansen passports. ${ }^{2}$

\section{Russians in the Pomeranian Voivodeship}

The first groups of Russians appeared in Pomerelia already before 1920. They were prisoners of war captured after devastating defeats suffered by the Russian forces in the East Prussian campaign in September 1914. Those soldiers were transported to hastily established camps. It is impossible to estimate precisely the number of POWs of particular nationalities based on the preserved archival materials as in the majority of the documents the German authorities would describe them as "Russian prisoners of war" without differentiating between nationalities. However, the tsar's army included, besides Russians, the representatives of other nations comprising the empire of the Romanovs - Ukrainians, Belarusians, Poles, Jews, Latvians, Tatars, and others. Those soldiers were also included among the tens of thousands of prisoners of war (POWs) captured by the German army after the latter won the First Battle of the Masurian Lakes and the Battle of Tannenberg.

As they had thought that the fighting on the Eastern Front would be delayed, the Germans were unprepared for such a great number of Russian POWs. Thus, often it was the POWs themselves who were forced to build the camps they were to inhabit. This was the situation in Pomerelia, where the German authorities established three camps for Russian POWs: in Tuchola, Czersk and Gdańsk. ${ }^{3}$ The living conditions in those camps were very difficult. Hard work (particularly in the beginning, during the construction of temporary housings), scarce food rations, and inadequate housing (the vast majority of buildings were dugouts) led to outbreaks of infectious diseases such as typhoid fever, dysentery, and cholera, which caused numerous fatalities among the POWs. ${ }^{4}$ The preserved archival materials reveal that during World War I there were about 40-50 thousand Russian POWs in Pomerelia (Polish part). Over 4800 of them died and were

\footnotetext{
${ }^{2}$ Zbigniew Karpus, "Jeńcy wojenni i emigracja polityczna z Rosji na Pomorzu w latach 1914-1939. Procesy asymilacyjne, stosunek miejscowego społeczeństwa," in Migracje polityczne i ekonomiczne w krajach nadbaltyckich w XIX i XX w., eds. Józef Borzyszkowski and Mieczysław Wojciechowski (Toruń: Instytut Historii i Archiwistyki Uniwersytetu Mikołaja Kopernika; Gdańsk: Instytut Historii Uniwersytetu Gdańskiego, 1995), 127.

${ }^{3}$ J. Jaśkowiak, "Ślady pruskiej zbrodni," Dziennik Bydgoski-Magazyn Aug 26-27 (1973): 15; Sylwester Bizan, Powiat i miasto Brodnica $w$ walkach o niepodlegtość 1914-1920, vol. 1 (Wąbrzeźno: published by the author, 1938), 33-34; Karpus, Jeńcy i internowani, 31-32; Za kratami i drutami obozów. Wspomnienia i notatki więźniów ideowych z lat 1914-1921, vol. 1 (Warszawa: Komitet Organizacyjny Zjazdu b. Więźniów Ideowych, 1931), 115-120; Andrzej Romanow, "Obóz jeniecki w Gdańsku w latach I wojny światowej," Rocznik Gdański LVI/2 (1996): 61-74; Zbigniew Karpus, Waldemar Rezmer, eds., Tuchola. Obóz jeńców i internowanych 1914-1923 (Torun: Wydawnictwo Naukowe UMK, 1997), XII-LXVI.

${ }^{4}$ Materials on living conditions of inmates in Tuchola and Czersk camps during WWI, vol. 4877 in Urząd Wojewódzki Pomorski w Toruniu (1920-1939) collection, Archiwum Państwowe w Bydgoszczy, Bydgoszcz, Poland (further: APB); Jaśkowiak, "Ślady pruskiej zbrodni," 15; Rev. Bolesław Makowski, unpublished memoir (1914-1918), Dział Rękopisów, Książnica Miejska, Toruń, Poland 26-27, 36.
} 
buried, mostly at camp cemeteries in Tuchola and Czersk as well as in other locations. ${ }^{5}$ Many POWs of other nations died in Pomerelia as well (see Table $1^{6}$ and $2^{7}$ ).

Table 1. POWs who died in 1914-1919 in the Tuchola and Czersk camps and were buried at camp cemeteries.

\begin{tabular}{|c|r|r|r|r|r|r|}
\hline Camp & Russian & Romanian & French & \multicolumn{1}{c|}{ Italian } & \multicolumn{1}{c|}{ British } & Total \\
\hline $\begin{array}{r}\text { Tuchola } \\
\text { (Czersk) }\end{array}$ & 1289 & 2471 & - & - & 1 & 3761 \\
\hline Total & 3252 & 5005 & 49 & 135 & 64 & 8505 \\
\hline
\end{tabular}

Table 2. The number and nationality of soldiers and POWs who died and were buried on the territory of the Pomeranian Voivodeship between December 1914 and July 1921.

\begin{tabular}{|l|r|r|r|}
\hline \multicolumn{1}{|c|}{ No. of fatalities } & \multicolumn{2}{c|}{ Officers } & \multicolumn{2}{c|}{$\begin{array}{c}\text { Privates } \\
\text { and non-coms }\end{array}$} \\
\cline { 1 - 2 } Nationality & 6 & 72 & 78 \\
\hline British & 4 & 45 & 49 \\
\hline French & - & 12 & $12^{\text {a }}$ \\
\hline Austrian & 103 & 4123 & $4226^{\text {a, b }}$ \\
\hline German & 15 & 479 & $494^{\text {a }}$ \\
\hline Polish & - & 3 & 3 \\
\hline Portuguese & 1 & 7651 & 7652 \\
\hline Romanian & - & 2 & 2 \\
\hline Serbian & & & \\
\hline
\end{tabular}

${ }^{5}$ Materials on Russians who died in Pomerelia during WWI, vol. 705 in Starostwo Powiatu Tucholskiego 1920-1939 collection, and vol. 24357 in Urząd Wojewódzki Pomorski w Toruniu (1920-1939) collection, APB.

${ }^{6}$ Lists of POWs who died in Tuchola in 1914-1920, vol. 24356 and 24357 in Urząd Wojewódzki Pomorski w Toruniu (1920-1939) collection, vol. 55 in Landratura Powiatu Tucholskiego 1939-1945 collection, APB.

${ }^{7}$ Minutiae of the foundation meeting on July 20, 1921 of Polski Żałobny Krzyż [Polish Mourning Cross] in Tuchola, vol. 705 in Starostwo Powiatu Tucholskiego (1920-1939) collection, APB; Rząd $i$ Wojsko, March 27 (1921). Documentation on POWs and soldiers deceased in the territory of Pomeranian voivodeship [a) they were wounded soldiers who died in hospitals located in Pomerelia; b) undoubtedly among the Russian and German soldiers there were Poles as well as representatives of other minorities (particularly in the Russian army). Polish and German statistics did not differentiate those nationalities], vol. 24283, 24317, 24298, 24316, 24311, 24312 and 24357 in Urząd Wojewódzki Pomorski w Toruniu (1920-1939) collection, APB. 


\begin{tabular}{|l|r|r|r|}
\hline Italian & - & 135 & 135 \\
\hline Russian & 15 & 4826 & $4841^{\mathrm{b}}$ \\
\hline Soviet POWs & - & 1867 & 1867 \\
\hline Total & $\mathbf{1 4 4}$ & $\mathbf{1 9 2 1 5}$ & $\mathbf{1 9 3 5 9}$ \\
\hline
\end{tabular}

The end of World War I and the defeat of Germany was a signal for the POWs in German camps to return home. This process began first in Pomerelia, from where Russian POWs began their travel back to their motherland, either legally in transports organized by German authorities or illegally. ${ }^{8}$ They moved east mostly along two routes - via Działdowo and Mława or Toruń and Włocławek. By spring 1919, practically all Russian POWs from the camps in Pomerelia and the nearby areas had been evacuated through these routes. Unguarded, the abandoned camps in Tuchola, Czersk and Gdańsk were then vandalised by the local population, with Czersk camp damaged most severely. ${ }^{9}$

As Poland took over Pomerelia in January and February 1920, no more prisoners of war remained in the camps in that area. Out of tens of thousands of Russian POWs who were interned in Pomerelia during World War I, by 1920 only 400-500 stayed. They were still employed as farmhands by local landowners and farmers and did not use the opportunity to return to Russia during the first phase of the evacuation. In spring 1921, the majority of Russians stayed in the powiats [counties] of Wąbrzeźno (73 people), Świecie (41 people), and Chojnice (35 people). ${ }^{10}$ Some of them were repatriated to the Soviet Russia after the Polish-Soviet War. The statistics compiled in the spring of 1924 at the time when the legal status of migrants from Russia was being regulated in Europe, including Poland - by the Pomeranian Voivodeship Office in Torun reveal that about 240 former Russian POWs from the time of World War I resided in the voivodeship. ${ }^{11}$ In the same year those people applied for identity documents (passports) to the Consulate of the Soviet Russia in Warsaw. They were unsuccessful, however, as the Consulate refused issuing such documents; thus they received the so-called Nansen passports (defining their legal status as stateless). ${ }^{12}$ That group of Russians evidently had become assimilated; many of them had married Polish women, as a result obtaining Polish citizenship. There were also few cases of conversion from Orthodox Christianity to Christianity among the

${ }^{8}$ Zbigniew Karpus, "Ewakuacja rosyjskich jeńców wojennych z Niemiec przez terytorium Polski w pierwszych miesiącach po odzyskaniu niepodległości (listopad 1918-październik 1919)," in Od obcego panowania do niepodległego państwa, ed. Mieczysław Wojciechowski (Toruń: Uniwersytet Mikołaja Kopernika, 1991), 75-92; Zbigniew Karpus, "Życie społeczno-kulturalne mniejszości rosyjskiej w Bydgoszczy w okresie międzywojennym," Kronika Bydgoska XI (1989): 111-112.

${ }^{9}$ Letter on the state of POW camps in Pomerelia from March 1920, vol. 12 in Oddział IV Naczelnego Dowództwa Wojska Polskiego z lat 1918-1920 (Sekcja Jeńców) collection, file no. I.301.10, Centralne Archiwum Wojskowe, Warszawa (further: CAW); Karpus, Jeńcy i internowani, $31-32$.

${ }^{10}$ Statistics on former Russian POWs from WWI residing in Pomerelia as of April 1921, vol. 5379 in Urząd Wojewódzki Pomorski w Toruniu (1920-1939) collection, APB.

${ }^{11}$ Statistics on former Russian POWs from WWI residing in Pomerelia in 1924, vol. 5092, ibid.

${ }^{12}$ Documentation of Russians residing in Pomerelia applying for Soviet passports in 1924, vol. 5379, ibid. 
former POWs, which were meticulously noted in reports by Polish authorities. ${ }^{13}$ Due to dispersion of its members and their low education level, that group did not undertake any attempts at integration, e.g. by creating their own associations or organizations. In their reports, Polish authorities emphasized loyalty of those Russians towards the Second Polish Republic.

Another group of Russians reached Pomerelia at the end of August 1920, following the victory of the Polish forces at the Battle of Warsaw, when tens of thousands of Bolshevik soldiers were captured. Lacking facilities for so many people, the military authorities decided to move part of the POWs to Pomerelia, to prisoner camp no. 7 in Tuchola, which had been operating already since mid-May 1920 (at that time the inmates were Ukrainian POWs from East Galicia). ${ }^{14}$ The idea to re-open another camp in Czersk was abandoned, however, due to its ill repute, dating back to World War I, and significant devastation of the dug-outs. The Bolshevik POWs remained in Tuchola from August 1920 to mid-October 1921, until the end of prisoner-of-war exchange between Poland and the Soviet Russia. Besides the camp in Strzałkowo (located between Stupca and Września), the camp in Tuchola was the largest camp for the Bolshevik POWs in Poland; at the end of March 1921 it held 11 thousand inmates. ${ }^{15}$ The prisoner headcount for the camp in Tuchola is presented in Table $3,{ }^{16}$ and the number of Bolshevik prisoners who died there - in Table $4 .{ }^{17}$

As a result of the POW exchange, the Russians remaining in Tuchola and other camps on Polish territory were sent home. Only a minority - over a thousand people — stayed in Poland and were granted political asylum. No such cases were recorded in Pomeranian voivodeship. ${ }^{18}$

${ }^{13}$ A list of POWs from WWI and the Polish-Soviet War residing in Pomerelia as of April 1, 1924, ibid.

${ }^{14}$ Description of the state of the POW camp no. 7 in Tuchola from May 1920, vol. 104, in Oddział I Sztabu Ministerstwa Spraw Wojskowych 1918-1921 collection, file no. I.300.7, CAW; Information on the opening of Tuchola camp from May 1920, vol. 12, in Oddział IV Naczelnego Dowództwa Wojska Polskiego z lat 1918-1920 (Sekcja Jeńców) collection, file no. I.301.10, CAW.

${ }^{15}$ Zbigniew Karpus, "Obóz Jeńców nr 7 w Tucholi (1914-październik 1921)," Studia i Materiały do Historii Wojskowości XXXVI (1994): 137-148; Karpus, Jeńcy i internowani, 90-120; Karpus, "Problem jeńców bolszewickich na terenie Dowództwa Okręgu Generalnego Pomorze w okresie sierpień 1920-październik 1921," Zeszyty Naukowe Wyższej Szkoty Oficerskiej im. gen. Józefa Bema XXVIII, no. 7 (1995): 286-287.

${ }^{16}$ W. Ogonowski, Kronika obozu jeńców w Tucholi z 1920 r. (manuscript), fond 309, State Archive of Lviv Oblast, Lviv, Ukraine; Karpus, Obóz Jeńców $n r$ 7, 143; Karpus, "Tuchola. Obóz jeńców i internowanych (1914-1922)," in Szkice tucholskie. W 650-lecie nadania praw miejskich Tucholi, ed. Włodzimierz Jastrzębski (Bydgoszcz-Tuchola: Wyższa Szkoła Pedagogiczna, 1996), 256-257.

${ }^{17}$ Lists of Bolshevik POWs who died in Tuchola camp in the years 1914-1922, vol. 24277, 24356 in Urząd Wojewódzki Pomorski w Toruniu (1920-1939) collection, APB; Documentation on founding of the Powiat Society of the Mourning Cross in Tuchola in 1925, vol. 704 in Starostwo Powiatu Tucholskiego (1920-1939) collection, APB; Protocol of Tuchola camp supervision of December 6, 1920, vol. 118 in Oddział I Sztabu Ministerstwa Spraw Wojskowych 1918-1921 collection, file no. I.300.7, CAW; Death reports of POWs in Tuchola camp in 1920-1921, vol. 61 in Biuro Wyznań Niekatolickich Ministerstwa Spraw Wojskowych 1919-1939 collection, file no. I.300.20, CAW; Communication no. 61 of May 30, 1921, vol. 329 in Dowództwo 4 Armii collection, file no. I.311.4, CAW; Karpus, "Problem jeńców bolszewickich," 289.

${ }^{18}$ Registration of former POWs residing in Pomerelia in 1924, vol. 5092 in Urząd Wojewódzki Pomorski w Toruniu (1920-1939) collection, APB; List of persons who arrived in Pomerelia from Russia until 1925, ibid. 
Table 3. Bolshevik POWs staying in the Tuchola camp between August 1920 and October 1921.

\begin{tabular}{|l|r|}
\hline \multicolumn{1}{|c|}{ Date } & No. of POWs in the camp \\
\hline 31 Aug 1920 & 4521 \\
\hline 30 Sep 1920 & 925 \\
\hline 31 Oct 1920 & 1329 \\
\hline 10 Nov 1920 & 4729 \\
\hline 5 Dec 1920 & 5308 \\
\hline 28 Jan 1921 & 7509 \\
\hline 5 Mar 1921 & 10999 \\
\hline 29 Apr 1921 & 9273 \\
\hline 27 May 1921 & 7559 \\
\hline 26 Jun 1921 & 5725 \\
\hline 23 Jul 1921 & 1834 \\
\hline 29 Sep 1921 & 720 \\
\hline 12 Oct 1921 & 152 \\
\hline
\end{tabular}

Table 4. Bolshevik POWs who died in the Tuchola camp between August 1920 and April 1921.

\begin{tabular}{|l|r|}
\hline \multicolumn{1}{|c|}{ Period } & No. of deaths \\
\hline 30 Aug-2 Nov 1920 & 437 \\
\hline $3-30$ Nov 1920 & 296 \\
\hline $1-31$ Dec 1920 & 333 \\
\hline $1-31$ Jan 1921 & 561 \\
\hline $1-28$ Feb 1921 & 157 \\
\hline $1-31$ Mar 1921 & 64 \\
\hline $1-30$ Apr 1921 & 19 \\
\hline Total & $\mathbf{1 8 6 7}$ \\
\hline
\end{tabular}

The third - and last — group of Russians arrived in Pomerelia at the end of December 1920. It included soldiers from the so-called $3^{\text {rd }}$ Russian Army commanded by General Boris Permikin, created on the territory of Poland to join fight against the Bolsheviks. When the fighting in the east ceased, this formation, like other allied ones (Ukrainians, Cossacks, the unit of Gen. Stanisław Bałachowicz) was detained by the Polish 
authorities and, in accordance with the provisions of Polish-Bolshevik ceasefire agreement, placed in a camp in Torun in the fortress buildings located on the left bank of the Vistula. ${ }^{19}$ The maximum number of the detained Russians from General Permikin's unit was more than 2,500, including women and children; a large group, approximately a third of that number, were officers (see Table 5) ${ }^{20}$ The camp in Torun operated up until the beginning of September 1921, when the Russians remaining there were sent to the camp in Tuchola. ${ }^{21}$ This was related to the progress made in the POW exchange between Poland and the Bolshevik Russia, due to which Polish authorities, for economic reasons, were able to gather the confined persons in several selected camps.

Table 5. Russians confined at the Internment Camp no. 15 in Torun between January and September 1921.

\begin{tabular}{|l|r|r|r|r|r|r|}
\hline \multirow{2}{*}{ Date } & \multicolumn{5}{|c|}{ Number of confined persons } & \multirow{2}{*}{ Total } \\
\cline { 2 - 7 } & Officers & Army clerks & Privates & Women & Children & \\
\hline End of Jan 1921 & 877 & - & 911 & - & - & 1788 \\
\hline 9 Feb 1921 & 789 & 76 & 1386 & 100 & 18 & 2369 \\
\hline 25 Feb 1921 & 843 & 91 & 1485 & 126 & 46 & 2591 \\
\hline 5 Mar 1921 & 632 & 90 & 1456 & 127 & 24 & 2329 \\
\hline 31 Mar 1921 & 643 & 87 & 1493 & 137 & 29 & 2389 \\
\hline 30 Apr 1921 & 674 & 88 & 1501 & 146 & 31 & 2437 \\
\hline 27 May 1921 & 709 & 92 & 1620 & 144 & 33 & 2598 \\
\hline 27 Jun 1921 & 647 & - & 1099 & 133 & 28 & 1907 \\
\hline 8 Jul 1921 & 731 & - & 1057 & 142 & 31 & 1961 \\
\hline 23 Aug 1921 & 510 & - & 547 & 137 & 41 & 1235 \\
\hline 6 Sep 1921 & 476 & - & 545 & 130 & 41 & 1192 \\
\hline 14 Sep 1921 & 417 & - & 266 & 116 & 39 & 840 \\
\hline
\end{tabular}

${ }^{19}$ Zbigniew Karpus, "Emigracja rosyjska i ukraińska w Toruniu w okresie międzywojennym," Rocznik Toruński (1983): 94-96; Zbigniew Karpus, "Rosjanie i Ukraińcy w Toruniu w latach 1920-1939," in Mniejszości narodowe i wyznaniowe w Toruniu w XIX i XX w., ed. Mieczysław Wojciechowski (Toruń: Wydawnictwo UMK, 1993), 81-84.

${ }^{20}$ List of POW and internment camps of March 1921, vol. 35a in Oddział IV Naczelnego Dowództwa Wojska Polskiego z lat 1918-1920 collection, file no. I.301.10, CAW; Communications on the situation of POWS and detained persons in camps for the period March-July 1921, vol. 402 in Gabinet Ministra Spraw Wojskowych 1918-1939 collection, file no. I.300.1/vol. 329 in Dowództwo 4 Armii collection, file no. I.311/vol. 27 in Oddział V Personalny Sztabu Ministerstwa Spraw Wojskowych 1920-1921 collection, file no. I.300.11, CAW.

${ }^{21}$ Zbigniew Karpus, "Obóz Internowanych nr 7 w Tucholi (wrzesień 1921-styczeń 1923)," in Mniejszości narodowe $i$ wyznaniowe $w$ województwie pomorskim $w$ okresie międzywojennym (1920-1939), 143-144. 
During their stay at the Torun camp, about 200 detainees, mostly officers with their families, were allowed to reside within the city. Such a permission - the so-called asylum card — was given to those inmates who found work. They were mostly employed by military units in auxiliary roles and by private enterprises. This group was the kernel of the future Russian diaspora in Torun. ${ }^{22}$ In other Pomeranian towns, such as Grudziądz or nearby Bydgoszcz, this process occurred in a similar way. ${ }^{23}$

After its previous inmates, i.e. Bolshevik POWs, were sent east, the camp in Tuchola became a place where Polish authorities gathered all Russian soldiers detained in Poland and so far placed in several smaller camps. In May 1922 the Tuchola camp held the largest number of Russians, 4,449 , some of them with families (see Table $6 .{ }^{24}$

Table 6. Russians confined in the Tuchola camp between September 1921 and September 1922.

\begin{tabular}{|c|c|c|c|c|}
\hline \multirow{2}{*}{ Date } & \multicolumn{4}{|c|}{ No. of detainees } \\
\hline & Total & Men & Women & Children \\
\hline 6 Sep 1921 & 1080 & 1018 & 49 & 13 \\
\hline 6 Oct 1921 & 3431 & 3092 & 254 & 85 \\
\hline 31 Jan 1922 & 4373 & 3949 & 314 & 110 \\
\hline 28 Feb 1922 & 4340 & 3914 & 211 & 115 \\
\hline 4 May 1922 & 4449 & 4068 & 302 & 79 \\
\hline 3 Jun 1922 & 3198 & 2784 & 296 & 118 \\
\hline $21 \mathrm{Jul} 1922$ & 2839 & 2439 & 285 & 115 \\
\hline 5 Sep 1922 & 2016 & 1658 & $281^{\prime}$ & 77 \\
\hline
\end{tabular}

The camp in Tuchola existed until November 1922, when the Polish authorities decided to close it due to the inmates' complains about poor living conditions. ${ }^{25}$ Those still confined there were moved to the camp in Strzałkowo, one of the two still operating camps (the other was Kalisz-Szczypiorno) for detained Russians and Ukrainians. When the camp in Tuchola was operational, the number of inmates was systematically decreasing. The greatest number of people used the amnesty proclaimed in the camps by the representatives of the Bolshevik government in the spring of 1922 and were

\footnotetext{
${ }^{22}$ List of detainees employed in Toruń in 1922, vol. 4872 in Urząd Wojewódzki Pomorski w Toruniu (1920-1939) collection, APB; Pomeranian Voivode's circular letter no. 112 of 1921, vol. 332 , ibid.

${ }^{23}$ Materials on the life of the Russian colony in Grudziądz in 1920-1939, vol. 30 in Rosyjski Komitet w Polsce 1918-1939 collection, microfilm no. 22898-22939, Archiwum Akt Nowych, Warsaw (further: AAN); Karpus, “Życie społeczno-kulturalne,” 111-112.

${ }^{24}$ Karpus, Jeńcy i internowani, 112-137; Karpus, “Obóz Internowanych nr 7 w Tucholi,” 145.

${ }^{25}$ Zbigniew Karpus, “Obóz Internowanych nr 7 w Tucholi," 145-157.
} 
repatriated to their homeland; others emigrated to France or Brazil. ${ }^{26}$ Only a small group of Russians (circa 400 people) managed to find work and settle in the Pomeranian Voivodeship. ${ }^{27}$ They resided mostly in larger cities - Toruń, Grudziądz, and Bydgoszcz.

The problem of refugees from Russia was ultimately settled in Poland in the middle of 1924, when Russians and other political migrants from Russia, who decided to stay in Poland, were issued Nansen passports and the status of stateless persons. At that time there were almost 850 Russians residing in the Pomeranian Voivodeship, including 250 World War I prisoners of war and about 600 political migrants and refugees. ${ }^{28}$ In the following years their number systematically decreased - in 1937 there were only 600 of them, ${ }^{29}$ which was caused by limited opportunities for finding work in the area, a situation particularly difficult for stateless persons during the Great Depression.

Immediately after arriving at the internment camps in Torun and then in Tuchola, the Russians began to organize their social life, i.e. opening schools for the illiterate and organizing different courses for officers. They also printed their own newspapers and magazines on duplicating machines: in the camp in Torun they published newspapers Nasza Gazeta and Donskiy Kozak as well as a satirical magazine Otzwuki, while in Tuchola - Zhive Slovo and satirical Pigmey. They also formed choirs, musical bands, and theatre troupes, which gave numerous concerts and performances not only for the inmates but also for the Polish society. Those events, which included e.g. the performances of operas Traviata and Rigoletto, aroused considerable interest among the citizens of Torun and received positive reviews in local papers. ${ }^{30}$ The Polish population - which was the most evident in Torun - offered whatever material aid they could afford to the Russians residing in the city.

The Russians who had left the camp and settled in Torun also integrated very quickly. As early as in spring 1921 they applied to register an organization named The Committee of Citizens of East Siberia and Far East. ${ }^{31}$ The city authorities did not support this initiative; likewise, in 1922 they did not register another organization, named the Russian Committee in Torun. This attitude of the authorities towards the attempts of the emigres from Russia to organize themselves was dictated by the fear that the dominant influence in this group would belong to pro-monarchy activists, hostile to Poland. Therefore the Polish authorities expelled a group of Russian monarchist activists from Warsaw to Gdańsk and in Torun they decided to detain the

${ }^{26}$ Report on the visit of Repatriation Commission in Tuchola camp on July 22, 1922, Repository 4 vol. 4872 in Urząd Wojewódzki Pomorski w Toruniu (1920-1939) collection, APB; Reports on the situation in Tuchola camp from May and June 1922, vol. 13445, 622 in Urząd Wojewódzki Pomorski w Toruniu (1920-1939) collection, APB.

${ }^{27}$ Materials on Russians granted asylum in Pomerelia in 1923-1924, vol. 5207 in Urząd Wojewódzki Pomorski w Toruniu (1920-1939) collection, APB; List of detainees employed in Toruń in 1922, vol. 4872 in Urząd Wojewódzki Pomorski w Toruniu (1920-1939) collection, APB.

${ }^{28}$ Reports of Voivodeship Headquarters of the State Police from 1925, vol. 4547, 5092, 4872 in Urząd Wojewódzki Pomorski w Toruniu (1920-1939) collection, APB.

${ }^{29}$ Nationality statistics of Pomeranian voivodeship for 1937, vol. 2950 in Urząd Wojewódzki Pomorski w Toruniu (1920-1939) collection, APB.

${ }_{30}$ Svoboda, May 12, 1921; Karpus, "Rosjanie i Ukraińcy w Toruniu," 83, 94.

${ }^{31}$ Application to establish a Russian organization in Torun in 1921, vol. 28 in Rosyjski Komitet w Polsce 1918-1939 collection, microfilm no. 22898-22939, AAN. 
initiators of establishing the Russian Committee in Strzałkowo. ${ }^{32}$ The first organizations of Russian migrants that were recognized by the Polish authorities began operating in Pomerelia after 1924, after the regulation of the legal status of refugees from Russia in Europe and in Poland was passed. At the same time the last internment camps were closed as well. In November 1925 a group of Russian refugees proposed the establishment of the first organization in Torun, which at that time had 100-120 thousand residents and was the home of the largest Russian diaspora in the Pomeranian Voivodeship. Their attempts were successful: a Torun Branch of the Warsaw-based Russian Committee for Supporting Migrants in Poland was opened in mid-1926 $6^{33}$ and operated until the beginning of World War II, with almost all members of the Russian community in Torun participating in its activities.

Much later, in 1938, another branch of the Committee was established in Grudziądz, where about 90 Russians lived with their families. The branch included twenty-two members, and its premises were located at 36 Lotnicza Street. The first chairman of the Grudziądz branch was Mikołaj Romanow (Nicolas Romanov), previously the plenipotentiary of the Committee for Supporting Migrants. ${ }^{34}$ However, it proved impossible to open a branch in Gdynia, where approximately 100 Russians with families lived in the late 1930s. There are only few mentions that an Orthodox Union existed in Gdynia in December 1938, but no information is found as to its character and activities. $^{35}$ No source confirms that Russian migrants tried to establish any organizations or associations in other Pomeranian towns.

What played a significant role in the process of integration of the Russian community in the society of the Pomeranian Voivodeship during the interwar period was religion. In Pomerelia there were two permanent Orthodox churches - in Toruń and in Grudziądz. The third one, in Tuchola, functioned only when there was a camp in town, first for the Bolshevik POWS and then for the detained. ${ }^{36}$ After the camp was closed, the church was closed as well. The Orthodox churches in Torun and Grudziadz served the Russian and Ukrainian migrants living in those towns as well as Polish soldiers of Orthodox faith who served in the military units garrisoned there from 1922. In June 1938 in Torun there were 1,299 Orthodox soldiers (mostly Belarusians, with some Ukrainians from Kresy Wschodnie [Eastern Borderlands]) and in Grudziądz 1,361. In total, about 4,200 soldiers of Orthodox faith served in all the military

${ }^{32}$ Protocols of Major B. Tymoschenko interrogation form May and June 1922, vol. 4872 in Urząd Wojewódzki Pomorski w Toruniu (1920-1939) collection, APB.

${ }_{33}$ Materials on Torun Branch of the Russian Committee for Supporting Migrants for 1925, vol. 28 in Archiwum miasta Torunia collection, Archiwum Państwowe w Toruniu, Toruń, Poland (further: APT).

${ }^{34}$ Materials on the life of the Russian colony in Torun in 1938-1939, vol. 30 in Rosyjski Komitet w Polsce 1918-1939 collection, microfilm no. 22898-22939, AAN.

${ }^{35}$ Situation report of the Government Commissioner in Gdynia on political movements and national minorities for December 1938, vol. 2300 in Komisariat Rządu w Gdyni collection, Archiwum Państwowe w Gdyni, Gdynia, Poland (further: APG); Nationality statistics for 1937, vol. 2950 in Urząd Wojewódzki Pomorski w Toruniu (1920-1939) collection, APB.

${ }^{36}$ List of clergy at the Orthodox Ministry of the District Headquarters of the District Corps No. VIII in Toruń, vol. 68 in Biuro Wyznań Niekatolickich Ministerstwa Spraw Wojskowych 1919-1939 collection, file no. I.300.20, CAW; Personal file of Rev. Capt. Stefan Rudyk, vol. 67, ibid; W. Ogonowski, Kronika obozu jeńców w Tucholi z 1920 r. (manuscript), fond 309, State Archive of Lviv Oblast, Lviv, Ukraine. 
garrisons in the Pomeranian Voivodeship. ${ }^{37}$ The Orthodox parishes were served by chaplains from the Orthodox Ministry of the District Headquarters of the District Corps no. VIII in Toruń: Stefan Rudyk, Grzegorz Kuryłas, Wiaczesław Wieżański, and Wiaczesław Rafalski. In Grudziądz, Rev. Capt. A. Kalinowicz carried out ministry for Orthodox soldiers as well as Russians and Ukrainians living in the town. One of the most important events was the ceremony of blessing the water, the so-called "Jordan," in which Poles also participated. ${ }^{38}$ Initially the Torun and Grudziądz Orthodox churches did not have permanent locations and often changed premises, usually rented from other religious communities - usually Protestant ones - active in those towns. For the Orthodox community in Torun, one of the most important events was the 1927 ceremony of consecrating their church in a temple located in Nowy Rynek and rented from the Evangelical parish; the Orthodox services were held in this building until $1939 .^{39}$ In 1926 in Torun, the local chaplain, Capt. Rudyk, and a group of his parishioners established the Orthodox Brotherhood. Its objective was integration of the people of Orthodox faith living in Torun and providing them with spiritual and material support when necessary. ${ }^{40}$ There were no permanent Orthodox churches in other towns of the Pomeranian Voivodeship inhabited by Russians and Ukrainians as well as soldiers of Orthodox; as a result, military chaplains ministered to the communities.

\section{Ukrainians in the Pomeranian Voivodeship}

For Ukrainians, the process of settling in Pomerelia and Torun took much longer than for Russians. This was mostly due to the fact that internment camps for soldiers from Russian units were located in the region and, after the camps were closed, part of those people found work and settled in the area permanently. In such circumstances, the emigrants from Ukraine encountered more difficulties in finding employment. They settled in Pomerelia gradually, following the liquidation of particular camps where they had been confined. The nearest internment camps for Ukrainians from the forces of ataman Symon Petlyura were located in Aleksandrów Kujawski and Strzałkowo. The former was closed in the autumn of 1921 and the latter - towards the end of $1923 .{ }^{41}$

The first groups of Ukrainians arrived in Pomerelia several months after the takeover of this region by Poland. They were the soldiers of the West Ukrainian People's Republic, captured by the Polish forces after the Kiev operation began. Approximately 12 thousand Ukrainians became POWs in Polish custody. The majority of privates were released and the officers were transferred to POW camps, including

${ }^{37}$ Information on soldiers of Russian Orthodox faith serving at the District Corps no. VIII in Toruń in 1938, vol. 61 in Biuro Wyznań Niekatolickich Ministerstwa Spraw Wojskowych 19191939 collection, file no. I.300.20, CAW; Waldemar Rezmer, "Mniejszości narodowe w Wojsku Polskim w okresie międzywojennym ze szczególnym uwzględnieniem Dowództwa Okręgu Korpusu nr VIII w Toruniu," in Mniejszości narodowe i wyznaniowe w województwie pomorskim w okresie międzywojennym (1920-1939), 125.

${ }^{38}$ Materials on followers of Russian Orthodox faith in the territory of District Corps no. VIII from 1937, vol. 68, 82, 91, in Biuro Wyznań Niekatolickich Ministerstwa Spraw Wojskowych 1919-1939 collection, file no. I.300.20, CAW.

${ }^{39}$ Vol. 28B in Archiwum miasta Torunia collection, APT; Stowo Pomorskie, Feb 26, 1927.

${ }^{40}$ Karpus, "Rosjanie i Ukraińcy w Toruniu," 87-88; Karpus, "Emigracja rosyjska i ukraińska," 105-106.

${ }^{41}$ Zbigniew Karpus, "Obozy uchodźców, jeńców i internowanych w Aleksandrowie Kujawskim w latach 1918-1921,” Zapiski Kujawsko-Dobrzyńskie 6 (Włocławek: Włocławskie Towarzystwo Naukowe, 1987), 53-58; Karpus, Jeńcy i internowani, 123-125. 
the one in Tuchola. The first Ukrainian soldiers reached the hastily renovated camp in Tuchola after 15 May 1920. After 1 July of that year, that camp became the only Polish place of confinement for Ukrainian officers from Galician formations. The highest number - over 2,100 officers - remained in Tuchola in mid-June 1920 and in subsequent months their number decreased (see Tab 7$)^{42}$ as they were released and sent to the places of permanent residence in East Galicia. Considering the short distance to the German border, many Ukrainians staying in the Tuchola camp used granted them leaves to escape and move west. During the several months the Ukrainian POWs spent in the camp, three of them died - one was shot during an escape attempt and two died of natural causes. ${ }^{43}$ The available archival materials do not note any cases of Ukrainians, who resided in and then were released from the camp in Tuchola, staying on the territory of the Pomeranian Voivodeship; thus, this group made no contribution to the Ukrainian community living in Pomerelia during the interwar period.

Table 7. Ukrainian POWs (from the West Ukrainian People's Republic forces) in the Tuchola camp between May 1920 and May 1921.

\begin{tabular}{|c|c|c|c|}
\hline \multirow{2}{*}{ Date } & \multicolumn{3}{|c|}{ Ukrainian POWs } \\
\hline & Total & Officers & Privates \\
\hline 29 May 1920 & 1228 & 386 & 842 \\
\hline 26 Jun 1920 & 2135 & 575 & 1860 \\
\hline 27 Jul 1920 & 1312 & 581 & 731 \\
\hline 26 Aug 1920 & 1036 & 528 & 508 \\
\hline 27 Sep 1920 & 888 & 468 & 420 \\
\hline 25 Oct 1920 & 864 & 409 & 455 \\
\hline 8 Dec 1920 & 600 & 200 & 400 \\
\hline 25 Feb 1921 & 220 & 197 & 6 \\
\hline 39 Mar 1921 & 149 & 75 & 74 \\
\hline 29 Apr 1921 & 125 & 57 & 68 \\
\hline 27 May 1921 & 103 & 52 & 51 \\
\hline
\end{tabular}

A small group of Ukrainian migrants came to Torun at the end of 1923, when the Polish government designated the city as the permanent residence site for a well-known anarchist Nestor Makhno (27 Oct 1887-25 Jul 1934). Makhno came to Poland illegally at the beginning of 1922 from Romania where he found shelter after escaping Ukraine. Afraid of Soviet protests, the Polish authorities arrested him and confined in a prison in Warsaw. He remained there for 14 months and then was sent to the Internment Camp no. 1 in Strzałkowo. On 1 December 1923 he was released from the camp together with

\footnotetext{
${ }^{42}$ Karpus, Rezmer, Tuchola. Obóz jeńców, 254.

43 Karpus, "Problem jeńców bolszewickich," 286.
} 
his family and closest co-workers and obliged to reside in Torun. ${ }^{44} \mathrm{He}$ and his wife Halina, their child, and several supporters, including his adjutant J. Chmara, arrived in Torun on 30 December 1923. After a brief stay at the Mazowiecki Hotel, Makhno moved to a flat at 29 Sienkiewicza Street. Soon he applied to the Ministry of the Interior for permission to leave for Germany with the possibility of returning to Poland. The Polish authorities agreed, but, at the same time, the consul in Berlin was ordered not to issue Makhno a return visa. However, the German consul in Torun rejected Makhno's application for a German visa. Another reason for postponing a trip to Berlin was also the fact that at the beginning of April 1924 Makhno tried to commit suicide. He changed flats two more times and, in May, he survived an assassination attempt. During his entire stay in the city, Makhno and people close to him were closely monitored by the police and military intelligence. Ultimately, on 2 July 1924 Makhno and his family left Torun for the Free City of Danzig (Gdańsk) without the right to return to Poland. His life continued to be tumultuous. After coming to Gdańsk, he was arrested in early September for not complying with the recommendations to leave the territory of the Free City of Danzig. In the end, the German authorities permitted him to move to Berlin. However, this journey had to be postponed as in December 1924 Makhno caught pneumonia and stayed in hospital (the hospital bills were paid by the Gdańsk authorities). After he recovered, he left the hospital and went to Berlin and, later, to Paris. ${ }^{45}$

The Ukrainian community living in Pomerelia first began to organize itself in Torun. This process began only in 1927, when Wiktor Łotocki, a representative of the Warsaw-based Central Ukrainian Committee (CUC), came to Toruń. His task was to establish a branch of the organisation in the city and powiat (county) of Torun. ${ }^{46}$ With the permission of the city authorities, the foundation meeting of the Torun Branch of the CUC took place on 13 November 1927 in the flat of J. Melnik at 13 Sobieskiego Street with twenty participants in attendence. The board elected at that time comprised the Board's president Michał Kaszczuk, the treasurer Włodzimierz Czagin, and the secretary Antoni Ptasznik. The main objective of this organization was to provide material and legal aid to Ukrainians living in the city and powiat. The funds came from membership fees and subventions received from the CUC. Shortly after the Branch was created, a Ukrainian library opened and a choir, a theatre troupe, and an amateur ballet group were established. Numerous theatrical performances and concerts were organized, the profits from which were used to aid the poorest emigrants. Every year the Committee organised a traditional Christmas meeting with gift exchange for children and New Year balls which served to integrate the Ukrainian community in

${ }^{44}$ Information on Nestor Makhno from July 9, 1924, vol. 5207 in Urząd Wojewódzki Pomorski w Toruniu (1920-1939) collection, APB; Letter from the Ministry of Interior to the Pomeranian Voivode of Dec 24, 1923, vol. 4714, ibidem; Letter of the starost to Torun City Council of Jan 2, 1924, ibid; S. Dmitrenko, Memoirs (typescript).

${ }^{45}$ Vol. 4714 in Urząd Wojewódzki Pomorski w Toruniu (1920-1939) collection, APB; Vol. 303 of the Komenda Wojewódzka Policji Państwowej w Toruniu (1920-1939), APB; Materials on Nestor Makho from the period December 1923-July 1925, vol. 55 in Oddział II Sztabu Ministerstwa Spraw Wojskowych z lat 1918-1921 collection (1772/89), file no. I.300.76, CAW; S. Dmitrenko, Memoirs (typescript); Dancigskij Kurier (Gdańsk), no. 2, Apr 7, 1924, 2.

${ }^{46}$ Letter of Wiktor Łotocki to Gen. W. Salski of Mar 10, 1931, vol. 160 in Sprzymierzona Armia Ukraińska collection, files no. I.380.1-20, CAW; vol. 176 of Archiwum miasta Torunia collection, APT. 
Torun. ${ }^{47}$ The Torun Branch operated without problems until 1930, when the Ukrainian diaspora split into two factions: the first one consisted of approximately fifty people, led by J. Sołowjew and M. Jarovy, while the other, comprising almost forty people, by the President of the Branch Michał Kaszczuk; the main cause for the split were financial matters. Already in January 1931 at a joint meeting a new board was elected, with Sołowjew at its head. ${ }^{48}$ The last President of the Torun Branch of the Central Ukrainian Committee noted in the preserved material was Bazyli Szewczuk, elected in $1935^{49}$. In 1928 the community of Ukrainian migrants in Torun decided to establish their own Orthodox Brotherhood. Those separatist tendencies directed against the already active Orthodox Brotherhood were caused by the controversies surrounding the celebration of the anniversary of Symon Petlyura's death - the Branch prepared a commemorative event with a mass in the Orthodox church as its central point. However, Rev. Grzegorz Kuryłas, the local chaplain whose brother was killed by Petlyura's soldiers in Volhynia in 1919, refused to participate in the celebration. That decision led to protests and official complaints, including those directed to Polish military authorities - the Ukrainians pointed out that at the same time a service to pray for General Pyotr Wrangel was held at the Orthodox church. The dispute ended in a compromise: ultimately the mass was celebrated by Dean Wieżański. ${ }^{50}$ The split in the Orthodox Brotherhood was averted and the relations between the Ukrainian and the Russian community during the entire interwar period remained neutral.

During the establishment of the Torun Branch of the CUC, Łotocki organized an educational group consisting of former officers and soldiers from Ukraine. Their meetings included courses aiming to raise military skills of the participants and prepare for another potential uprising in Ukraine. Until 1934 the educational group, consisting of twenty-eight participants, was chaired by Łotocki; when he left Torun, this role fell to Chmara. ${ }^{51}$

It was not until in November 1933 when another branch of the CUC began its operations in the largest community of Ukrainians in Pomerelia, this time in Gdynia. It consisted of twenty-four members; the president was Dymitr Ostapczuk, his deputy Iwan Bajko, the secretary - Wasyl Pohorylec, and the treasurer - Iwan Taborczyk. The change in the leadership took place in 1938, when Iwan Gorba became the

${ }^{47}$ Weekly reports on the life of national minorities for September and October 1929, vol. 175 of Archiwum miasta Torunia collection, APT; Karpus, "Emigracja rosyjska i ukraińska," $109-110$.

${ }^{48}$ Letter from District Corps no. VIII to Pomeranian Voivode's Office of Jun 2, 1930, vol. 591 in Oddział II Sztabu Ministerstwa Spraw Wojskowych z lat 1918-1921 collection (1772/89), file no. I.300.76, CAW; File on Ukrainians in Torun for years 1928-1936, vol. 160 in Sprzymierzona Armia Ukraińska collection, files no. I.380.1-20, CAW.

${ }^{49}$ List of branches of the Central Ukrainian Committee for 1935, vol. 108 in Sprzymierzona Armia Ukraińska collection, files no. I.380.1-20, CAW; Starost's situational report, vol. 13 in Starostwo Grodzkie w Toruniu 1920-1939 collection, APT.

${ }^{50}$ Intelligence report from Sep 23, 1928, vol. 591 in Oddział II Sztabu Ministerstwa Spraw Wojskowych z lat 1918-1921 (1772/89), file no. I.300.76, CAW; Letter from District Corps no. VIII to Bureau of Non-Catholic Faiths of the Ministry of Military Affairs of June 27, 1928, ibid; Open letter of the Torun Branch of the CUC to Rev. Wieżański of June 11, 1928, ibidem.

${ }^{51}$ Mobilization regions of the Ukrainian People's Republic in Poland in 1935, vol. 89 in Sprzymierzona Armia Ukraińska collection, files no. I.380.1-20, CAW; File on Ukrainians in Toruń for 1928-1936, ibid. 
president, Sawa Krywoboczenko — a secretary, and Władysław Szewczenko a treasurer. $^{52}$

The Ukrainians, who migrated during the interwar period to Pomerelia, were not only people from Dnieper Ukraine, but also Polish citizens from East Galicia. They found employment mostly in tax offices and courts and their number increased with the development of Gdynia. The informal leaders of the Galicians in Torun were W. Zathaj, a tax clerk, and Counsel Burczyński, a former minister of justice in the government of the West Ukrainian People's Republic. Their activity was closely observed by the state police. ${ }^{53}$

Groups of dozen or so Ukrainians from East Galicia also worked in different state offices or educational institutions in Grudziądz (including Adamski, Hołowiecki, Mryc, Mozewicz, Dywoser, Krawec, Truba, Filipczuk, dr Kiezuń), Wąbrzeźno, Działdowo, and Starogard Gdański. In 1936, five teachers of Ukrainian nationality worked in Świecko powiat: in Świecie — Eugenia Balińska, in Przechowo - Olga Wachniakówna, in Warlubie - Katarzyna Stasiówna, and in Osie - Stefania and Grzegorz Łumikowski. The officers of the state police from the powiats inhabited by Ukrainians emphasized in their reports that the latter's attitude towards the Polish state is unquestionable. ${ }^{54}$

People from East Galicia, mostly members of the Greek Catholic church, unsuccessfully attempted to establish their own parish in Torun in 1935. The initiative was opposed by both the bishop of the Chełmno diocese, Stanisław Okoniewski, and the Lviv Metropolitan bishop of the Greek Catholic Church, Andrij Szeptycki. ${ }^{55}$

During the entire interwar period the Ukrainian community in Pomerelia including both political migrants and Polish citizens - increased steadily due to the influx of Ukrainians to rapidly developing Gdynia where the Ukrainian diaspora was the largest. According to the administration of the Pomeranian Voivodeship, 466 Ukrainians lived there in 1937, most of them were Polish citizens. In the same year Torun, the capital of the voivodeship, was a home to 140 Ukrainians, which made it the second largest Ukrainian community in the area. In contrast to Gdynia, the majority of Ukrainians living in Torun were political migrants due to the proximity of the camp in Aleksandrów Kujawski. Additionally, a significant group of Ukrainians (86 people) resided in Wąbrzeźno powiat. Altogether, in 1931 about 400 Ukrainians (both migrants and the citizens of the Second Polish Republic) lived on the territory of the Pomeranian Voivodeship, in 1936 - 760, and in 1937 - approximately 1,700 (including almost 400 political migrants). ${ }^{56}$ The size of Ukrainian communities in particular towns and counties of Pomerelia is presented in Table $8 .^{57}$

52 Vol. 30056, 5207 in Urząd Wojewódzki Pomorski w Toruniu (1920-1939) collection, APB; Materials on Ukrainians in Pomerelia for years 1927-1936, vol. 124/2300 in Komisariat Rządu w Gdyni collection, APG.

${ }^{53}$ Report of District Corps no. VIII to Dept. II of the Ministry of Military Affairs on Ukrainian underground movement in the territory of Pomeranian voivodeship for 1927, vol. 591 in Oddział II Sztabu Ministerstwa Spraw Wojskowych z lat 1918-1921 collection (1772/89), file no. I.300.76, CAW.

${ }^{54}$ Materials on Ukrainians living in Pomerelia for 1920-1939, vol. 981 in Oddział II Sztabu Ministerstwa Spraw Wojskowych z lat 1918-1921 collection (1772/89), file no. I.300.76, CAW; Report of the State Police Headquarters in Świecie for 1936, vol. 421 in Starostwo Powiatu Świeckiego 1920-1939 collection, APB.

${ }^{55}$ Dzień Pomorski, Sep 5, 1931; Karpus, "Emigracja rosyjska i ukraińska,” 110.

${ }^{56}$ List of Ukrainians in Torun from 1934, vol. 116 in Sprzymierzona Armia Ukraińska collection, files no. I.380.1-20, CAW; File on Ukrainians in Torun for 1928-1936, vol. 160, ibid; Letter from District Corps no. VIII to Pomeranian Voivode's Office of Jun 2, 1930, vol. 591 in 


\section{Concluding Remarks}

The relations between the Russian and Ukrainian communities living in Pomerelia and the Polish population were neutral. During the entire interwar period no major incidents or conflicts between those groups were noted. The Poles attempted to help the migrants from Russia as much as possible, especially those who had just arrived in Pomerelia. Their positive attitude can be confirmed by numerous notices in the local papers informing about ventures undertaken by migrant communities and kind reports on their progression. The attitude of other churches to the followers of Orthodox Christianity was also positive, which was demonstrated by renting unused religious objects for Orthodox services.

Table 8. Ukrainians residing in the Pomeranian Voivodeship in 1937.

\begin{tabular}{|c|c|c|c|}
\hline \multirow{2}{*}{ Powiat } & \multirow{2}{*}{ Total no. of inhabitants } & \multicolumn{2}{|c|}{ Ukrainians and Russians } \\
\hline & & Number & $\%$ \\
\hline Brodnica & 57628 & 22 & 0.04 \\
\hline Chełmno & 56573 & 19 & 0.03 \\
\hline Chojnice & 82191 & 28 & 0.03 \\
\hline Działdowo & 47517 & 47 & 0.10 \\
\hline Gdynia miasto & 110195 & 466 & 0.42 \\
\hline Grudziądz powiat & 45635 & - & - \\
\hline Grudziądz township & 58461 & 18 & 0.03 \\
\hline Kartuzy & 69412 & 41 & 0.06 \\
\hline Kościerzyna & 55429 & 42 & 0.08 \\
\hline Lubawa & 54559 & 8 & 0.01 \\
\hline Morski & 99127 & 5 & - \\
\hline Sępólno Krajeńskie & 31488 & 4 & 0.01 \\
\hline Starogard & 74486 & 9 & 0.01 \\
\hline Świecie & 95550 & 15 & 0.02 \\
\hline Tczew & 71256 & 46 & 0.07 \\
\hline Toruń powiat & 66556 & 55 & 0.08 \\
\hline Toruń township & 64831 & 140 & 0.22 \\
\hline
\end{tabular}

Oddział II Sztabu Ministerstwa Spraw Wojskowych z lat 1918-1921 collection (1772/89), file no. I.300.76, CAW; Population statistics of Pomeranian voivodeship for 1931-1937, vol. 2950, 30056 in Urząd Wojewódzki Pomorski w Toruniu (1920-1939) collection, APB.

${ }^{57}$ Population statistics of Pomeranian voivodeship for 1937, vol. 30056 in Urząd Wojewódzki Pomorski w Toruniu (1920-1939) collection, APB. 


\begin{tabular}{|l|r|r|r|}
\hline Tuchola & 37807 & 32 & 0.09 \\
\hline Wąbrzeźno & 53488 & 86 & 0.16 \\
\hline Pomeranian voivodeship & 1232189 & 1683 & 0.19 \\
\hline
\end{tabular}

It should be stressed that both the Russian and Ukrainian communities were loyal towards the Polish state and government, which could be confirmed by church services and commemorative celebrations held on Polish national holidays or the birthday of Marshall Józef Piłsudski. ${ }^{58}$ The Polish authorities highlighted the loyalty of those communities in their reports and, in the second half of the $1930 \mathrm{~s}$, ceased to focus as much attention on them. For the entire interwar period, the attitude of Russian and Ukrainian residents of Pomerelia towards Poland contrasted with that of the German minority living in this area.

\section{BIBLIOGRAPHY}

Archiwum miasta Torunia collection, vol. 28, 174, 175, 176. Archiwum Państwowe w Toruniu, Torun, Poland.

Bizan, Sylwester. Powiat i miasto Brodnica w walkach o niepodległość 1914-1920, vol 1. Wąbrzeźno: published by the author, 1938.

Biuro Wyznań Niekatolickich Ministerstwa Spraw Wojskowych 1919-1939 collection, vol. 61, 67, 68, 82, 91, file no. I.300.20. Centralne Archiwum Wojskowe, Warsaw, Poland.

Dancigskij Kurier (Gdańsk), no. 2, Apr 7, 1924.

Dmitrenko, S. Memoir (typescript).

Dowództwo 4 Armii collection, vol. 329, file no. I.311.4. Centralne Archiwum Wojskowe, Warsaw, Poland.

Dzień Pomorski, Sep 5, 1931.

Gabinet Ministra Spraw Wojskowych 1918-1939 collection, vol. 402, file no. I.300.1. Centralne Archiwum Wojskowe, Warsaw, Poland.

Jaśkowiak, J. "Ślady pruskiej zbrodni.” Dziennik Bydgoski - Magazyn, August 26-27 (1973): 15 .

Karpus, Zbigniew. "Emigracja rosyjska i ukraińska w Toruniu w okresie międzywojennym." Rocznik Toruński (1983): 94-96.

Karpus, Zbigniew. "Ewakuacja rosyjskich jeńców wojennych z Niemiec przez terytorium Polski w pierwszych miesiącach po odzyskaniu niepodległości (listopad 1918-październik 1919).” In Od obcego panowania do niepodległego państwa, ed. Mieczysław Wojciechowski, 7592. Toruń: Uniwersytet Mikołaja Kopernika, 1991.

Karpus, Zbigniew. Jeńcy i internowani rosyjscy i ukrainscy w Polsce w latach 1918-1924. Toruń: Wydawnictwo Adam Marszałek, 1991.

Karpus, Zbigniew. "Jeńcy wojenni i emigracja polityczna z Rosji na Pomorzu w latach 19141939. Procesy asymilacyjne, stosunek miejscowego społeczeństwa.” In Migracje polityczne i ekonomiczne w krajach nadbałtyckich w XIX i XX w., ed. Józef Borzyszkowski and Mieczystaw Wojciechowski, 133-134. Toruń: Instytut Historii i Archiwistyki Uniwersytetu Mikotaja Kopernika; Gdańsk: Instytut Historii Uniwersytetu Gdańskiego, 1995.

${ }^{58}$ Vol. 174 in Archiwum miasta Torunia collection, APT; Karpus, "Emigracja rosyjska i ukraińska," 109; Zbigniew Karpus, "Jeńcy wojenni i emigracja," in Migracje polityczne i ekonomiczne w krajach nadbaltyckich w XIX $i$ XX w., eds. Józef Borzyszkowski, Mieczysław Wojciechowski (Toruń: Instytut Historii i Archiwistyki Uniwersytetu Mikołaja Kopernika; Gdańsk: Instytut Historii Uniwersytetu Gdańskiego, 1995), 133-134. 
Karpus, Zbigniew. "Obóz Internowanych nr 7 w Tucholi (wrzesień 1921-styczeń 1923).” In Mniejszości narodowe $i$ wyznaniowe $w$ województwie pomorskim $w$ okresie międzywojennym (1920-1939), ed. Mieczysław Wojciechowski, 143-144. Toruń: Wydawnictwo Adam Marszałek, 1991.

Karpus, Zbigniew. "Obozy uchodźców, jeńców i internowanych w Aleksandrowie Kujawskim w latach 1918-1921.” Zapiski Kujawsko-Dobrzyńskie 6 (1987): 53-58. Włocławek: Włocławskie towarzystwo Naukowe.

Karpus, Zbigniew. “Obóz Jeńców nr 7 w Tucholi (1914-październik 1921).” Studia i Materiały do Historii Wojskowości XXXVI (1994): 137-148.

Karpus, Zbigniew. "Problem jeńców bolszewickich na terenie Dowództwa Okręgu Generalnego Pomorze w okresie sierpień 1920-październik 1921." Zeszyty Naukowe Wyższej Szkoty Oficerskiej im. gen. Józefa Bema XXVIII, no. 7 (1995): 286-287.

Karpus, Zbigniew. "Rosjanie i Ukraińcy w Toruniu w latach 1920-1939." In Mniejszości narodowe $i$ wyznaniowe $w$ Toruniu w XIX $i$ XX w., ed. Mieczysław Wojciechowski, 81-84. Toruń: Wydawnictwo UMK, 1993.

Karpus, Zbigniew, “Tuchola. Obóz jeńców i internowanych (1914-1922).” In Szkice tucholskie. W 650-lecie nadania praw miejskich Tucholi, ed. Włodzimierz Jastrzębski, 256-257. Bydgoszcz-Tuchola: Wyższa Szkoła Pedagogiczna, 1996.

Karpus, Zbigniew. "Życie społeczno-kulturalne mniejszości rosyjskiej w Bydgoszczy w okresie międzywojennym.” Kronika Bydgoska XI (1989): 111-112.

Karpus, Zbigniew and Waldemar Rezmer, eds. Tuchola. Obóz jeńców i internowanych 19141923. Toruń: Wydawnictwo Naukowe UMK, 1997.

Komenda Wojewódzka Policji Państwowej w Toruniu (1920-1939) collection, vol. 303. Archiwum Państwowe w Bydgoszczy, Bydgoszcz, Poland.

Letter on the state of POW camps in Pomerelia from March 1920, vol. 12 in Oddział IV Naczelnego Dowództwa Wojska Polskiego z lat 1918-1920 (Sekcja Jeńców) collection, file no. I.301.10. Centralne Archiwum Wojskowe, Warsaw, Poland.

List of POW and internment camps of March 1921, vol. 35a in Oddział IV Naczelnego Dowództwa Wojska Polskiego z lat 1918-1920 collection, file no. I.301.10. Centralne Archiwum Wojskowe, Warsaw, Poland.

List of POWs who died in Tuchola in 1914-1920, vol. 55 in Landratura Powiatu Tucholskiego 1939-1945 collection. Archiwum Państwowe w Bydgoszczy, Bydgoszcz, Poland.

Makowski, Rev. Bolesław. Unpublished memoir (1914-1918). Dział Rękopisów, Książnica Miejska, Toruń, Poland.

Materials on Ukrainians in Pomerelia for years 1927-1936, Komisariat Rządu w Gdyni collection, vol. 124/2300. Archiwum Państwowe w Gdyni, Gdynia, Poland.

Oddział I Sztabu Ministerstwa Spraw Wojskowych 1918-1921 collection, vol. 104, 118, file no. I.300.7. Centralne Archiwum Wojskowe, Warsaw, Poland.

Oddział II Sztabu Ministerstwa Spraw Wojskowych z lat 1918-1921 collection (1772/89), vol. 55, 591, 981 file no. I.300.76. Centralne Archiwum Wojskowe, Warsaw, Poland.

Oddział V Personalny Sztabu Ministerstwa Spraw Wojskowych 1920-1921 collection, vol. 27, file no. I.300.11. Centralne Archiwum Wojskowe, Warsaw, Poland.

Ogonowski, W. Kronika obozu jeńców w Tucholi z 1920 r. (manuscript), fond 309. State Archive of Lviv Oblast, Lviv, Ukraine.

Report of the State Police Headquarters in Świecie for 1936, vol. 421 in Starostwo Powiatu Świeckiego 1920-1939 collection, Archiwum Państwowe w Bydgoszczy, Bydgoszcz, Poland.

Rezmer, Waldemar. "Mniejszości narodowe w Wojsku Polskim w okresie międzywojennym ze szczególnym uwzględnieniem Dowództwa Okręgu Korpusu nr VIII w Toruniu.” In Mniejszości narodowe $i$ wyznaniowe $w$ województwie pomorskim $w$ okresie międzywojennym (1920-1939), ed. Mieczysław Wojciechowski, 115-141. Torun: Wydawnictwo Adam Marszałek, 1991.

Romanow, Andrzej. "Obóz jeniecki w Gdańsku w latach I wojny światowej.” Rocznik Gdański LVI/2 (1996): 61-74. 
Rosyjski Komitet w Polsce 1918-1939 collection, vol. 28, 30, microfilm no. 22898-22939, Archiwum Akt Nowych, Warsaw, Poland.

Rzad i Wojsko, March 27 (1921).

Situation report of the Government Commissioner in Gdynia on political movements and national minorities for December 1938, Komisariat Rządu w Gdyni collection, vol. 2300. Archiwum Państwowe w Gdyni, Gdynia, Poland.

Stowo Pomorskie, Feb 26, 1927.

Sprzymierzona Armia Ukraińska collection, vol. 89, 108, 116, 160, files no. I.380.1-20. Centralne Archiwum Wojskowe, Warsaw, Poland.

Starostwo Grodzkie w Toruniu 1920-1939 collection, Vol. 13. Archiwum Państwowe w Toruniu, Torun, Poland.

Starostwo Powiatu Tucholskiego 1920-1939 collection, vol. 704, 705. Archiwum Państwowe w Bydgoszczy, Bydgoszcz, Poland.

Svoboda, May 12 (1921).

Urząd Wojewódzki Pomorski w Toruniu (1920-1939) collection, vol. 332, 2950, 4547, 4714, 4872, 4877, 5092, 5207, 5379, 24277, 24283, 24317, 24298, 24316, 24311, 24312, 24356, 24357, 30056. Archiwum Państwowe w Bydgoszczy, Bydgoszcz, Poland.

Za kratami i drutami obozów. Wspomnienia i notatki więźniów ideowych z lat 1914-1921, vol. 1. Warszawa: Komitet Organizacyjny Zjazdu b. Więźniów Ideowych, 1931.

\section{POLITICAL EMIGRANTS, PRISONERS OF WAR AND INTERNED PERSONS FROM RUSSIA AND UKRAINE IN POMERELIA (GDAŃSK POMERANIA) IN 1914-1939}

The article focuses on the Russian and Ukrainian residents of Pomeranian Voivodeship during the inter-war period, particularly those who came first as prisoners of war during World War I and the Polish-Soviet war as well as members of the White Russian forces detained in Poland after the latter conflict ended. Based on archival sources, the text traces the origins of those communities, presenting in detail situation in the camps, differences in assimilation attempts between specific groups of prisoners/migrants after release, as well as the later life of those communities in Pomerelia towns, including the question of religious worship. A separate part is devoted to Ukrainian economic migrants.

KEY WORDS: prisoners of war, Russians, Ukrainians, Pomerelia, Pomeranian voivodeship

\section{POLITYCZNI EMIGRANCI, JEŃCY WOJENNI I OSOBY INTERNOWANE Z ROSJI I UKRAINY NA TERENACH POMORZA GDAŃSKIEGO W LATACH 1914-1939}

Artykuł koncentruje się na Rosjanach i Ukraińcach, którzy w okresie międzywojennym zamieszkiwali w województwie pomorskim - przede wszystkim na tych, którzy trafili tam jako jeńcy wojenni podczas pierwszej wojny światowej i wojny polsko-bolszewickiej, a także członkach Białej Armii internowanych w Polsce po zakończeniu tego drugiego konfliktu. Na podstawie źródeł archiwalnych tekst analizuje pochodzenie różnych grup osiedleńców, przedstawiając szczegółowo sytuację w obozach a także różnice pomiędzy próbami asymilacji podejmowanymi przez poszczególne grupy byłych jeńców oraz emigrantów. Artykuł opisuje też późniejsze życie tych wspólnot w miastach Pomorza Gdańskiego, w tym kwestię kultu religijnego. Osobna część poświęcona jest emigrantom z Ukrainy, przybywającym na Pomorze głównie w celach zarobkowych.

SŁOWA KLUCZOWE: jeńcy wojenni, Rosjanie, Ukraińcy, Pomorze, województwo pomorskie. 


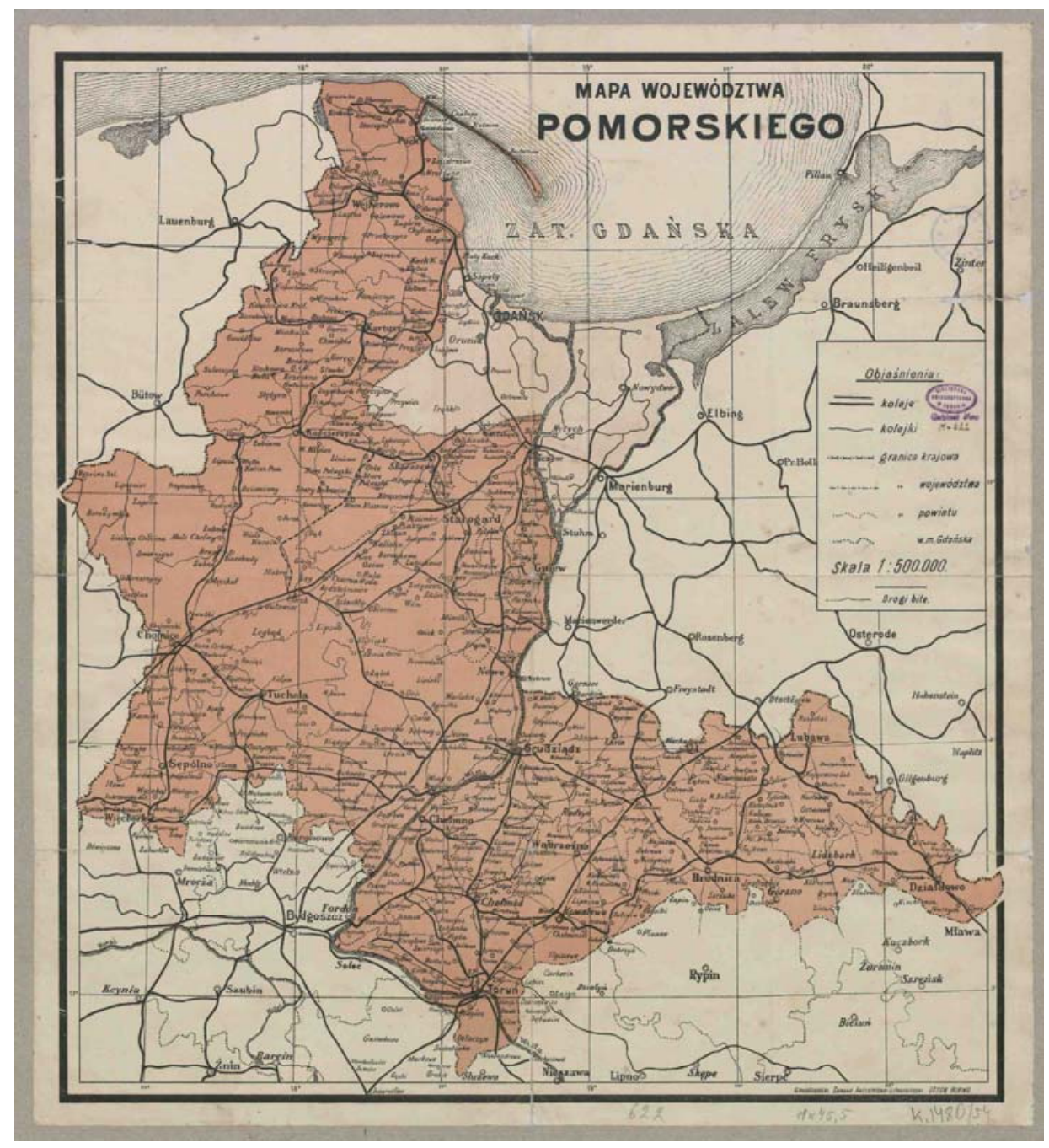

Map of Pomeranian Voivodeship in 1920-1937

Source: The collection of the Library of the Nicolaus Copernicus University in Torun (https://kpbc.umk.pl/dlibra/publication/81027/edition/87572/content) 
